\title{
Age, growth and population structure of Acanthocardia tuberculata (Bivalvia: Cardiidae) in the eastern Adriatic Sea
}

\author{
MELITA PEHARDA, DARIA EZGETA-BALIĆ, MARGITA RADMAN, \\ NELA SINJKEVIĆ, NEDO VRGOČ and IGOR ISAJLOVIĆ \\ Institute of Oceanography and Fisheries, Šetalište Ivana Meštrovića 63, 21000 Split, Croatia. E-mail: ezgeta@izor.hr
}

\begin{abstract}
SUMMARY: A study of the age, growth and population structure of Acanthocardia tuberculata from the eastern Adriatic Sea was carried out. The condition index analysis identified one reproductive peak, which occurred between April and May, for a population of A. tuberculata in the Cetina River estuary with uni-modal recruitment. Annual growth rings on the external shell surface consisted of a dark ring deposited during the summer-autumn period and a light ring deposited during winter-spring. This was validated by acetate peels of shell sections and marginal increment analysis. Shell lengths of aged specimens ranged from 19.7 to $62.9 \mathrm{~mm}$ (mean $=41.21 \pm 8.96 \mathrm{~mm}$ ). Estimated ages ranged from 5 months to 11 years, with mean values of 2.1, 2.4 and 3.1 years for Rab Island, Pag Bay and the Cetina River estuary respectively. Shell deposition is fastest during the first two years of life and significantly decreases after the $4^{\text {th }}$ year. The growth parameters $\mathrm{L}_{\infty}$ and $\mathrm{k}$ were estimated using the Gulland-Holt method and by fitting length at age data to a von Bertalanffy growth curve. Values of $\mathrm{L}_{\infty}$ ranged from $52.6 \mathrm{~mm}$ (Rab Island) to $59.7 \mathrm{~mm}$ (Pag Bay). The growth constant $\mathrm{k}$ showed greater variations $(0.49$ to 0.77 year ${ }^{-1}$ ), while growth performance index values $\left(\varnothing^{\prime}\right)$ ranged from 3.13 to 3.36 .
\end{abstract}

Keywords: Cardiidae, Mediterranean, age, growth, population structure, longevity, condition index.

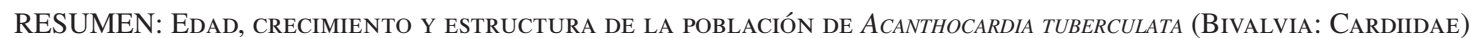
DE LA ZONA ORIENTAL DEL MAR ADRIÁTICO. - Se ha estudiado la edad, crecimiento y estructura de la población de Acanthocardia tuberculata de la zona oriental del mar Adriático. El índice de condición identifica un pico reproductivo que ocurre entre abril y mayo en la población de A. tuberculata del estuario del río Cetina, con reclutamiento unimodal. Los anillos de crecimiento anual en la superficie externa de la concha consistieron en un anillo oscuro depositado durante el verano-otoño y un anillo claro depositado durante el invierno-primavera. Se realizó una validación mediante el empleo de réplicas de acetato realizadas sobre secciones de la concha y el análisis de los incrementos marginales. La longitud de los especímenes datados osciló entre 19.7 a $62.9 \mathrm{~mm}$ (media $=41.21 \pm 8.96 \mathrm{~mm}$ ). Las edades estimadas oscilan entre 5 meses y 11 años, con valores medios de 2.1, 2.4 y 3.1 años en la isla de Rab, Pag bahía y el estuario del río Cetina, respectivamente. La deposición de concha es más rápida durante los dos primeros años de vida y disminuye significativamente a partir del cuarto año. Los parámetros de crecimiento $\mathrm{L}_{\infty}$ y $\mathrm{K}$ se calcularon utilizando el método de Gulland-Holt, ajustando los datos de longitud-edad a la curva de crecimiento de von Bertalanffy. Los valores de $\mathrm{L}_{\infty}$ estimados variaron entre $52.6 \mathrm{~mm}$ (Isla de Rab) y $59.7 \mathrm{~mm}$ (Pag bahía). La constante de crecimiento k mostró grandes variaciones $\left(0.49\right.$ a $\left.0.77 \mathrm{año}^{-1}\right)$, mientras que el índice de rendimiento de crecimiento ( $\left.\varnothing^{\prime}\right)$ osciló entre 3.13 y 3.36 .

Palabras clave: Cardiidae, Mediterráneo, edad, crecimiento, estructura de la población, longevidad, índice de condición.

\section{INTRODUCTION}

The cockle Acanthocardia tuberculata (Linnaeus, 1758) lives on sand, mud or gravel bottoms from the intertidal zone to depths of $100 \mathrm{~m}$. It is distributed from the British isles south to Morocco and the Mediterranean (Zavodnik and Šimunović 1997, Poppe and Goto 2000). There have been some previous studies on the biology of this species, notably on the accumulation of biotoxins (Berenguer et al. 1993, Tagmouti-Talha et al. 
2000, Vale and Sampayo 2002, Sagou et al. 2005, Vale and Taleb 2005, Takati et al. 2007). Other studies have focused on analyzing metal concentrations (Hornung 1989), reproduction (Marano et al. 1980), shell structure (Zolotoybko and Quintana 2002), the importance in the diet of the labrid Xyrichtys novacula (Castriota et al. 2005), and gene organization of the mitochondrial genome (Dreyer and Steiner 2006). Distribution data have been provided in several publications (e.g. HrsBrenko et al. 1998, Jukić et al. 1998, Zenetos et al. 2005, Šiletić 2006, Rufino et al. 2010).

A. tuberculata currently has little commercial value; however, in Spain and Morocco it is exploited by the canning industry (Taleb et al. 2001, Vale and Sampayo 2002, Ramón et al. 2005), and therefore fisheries could expand further. In Spanish waters this species is harvested together with other soft bottom species such as the smooth venus clam (Callista chione), the striped venus clam (Chamelea gallina), the wedge clam (Donax trunculus) and the king scallop (Pecten maximus). In the Spanish part of the Alboran Sea inshore harvesting is performed by a large dredge fleet of small shellfishing boats, while on the continental shelf and slope it is carried out by a trawler fleet (Robles 2010). Along the south coast of Portugal A. tuberculata is one of the most abundant bivalve species at depths between 3 and $15 \mathrm{~m}$ (Rufino et al. 2010). Along the west Adriatic coast, where fishing with hydraulic dredges is intensive, this species is collected as bycatch of the clam (Chamelea gallina) fishery (Morello et al. 2005). In the parts of the Adriatic Sea where the present study was conducted, the use of hydraulic dredges or other gears for bivalve harvesting is prohibited (Official Gazette 63/2010), as is trawling, and thus the species cannot be harvested as a bycatch. In these areas bivalves are only collected by SCUBA diving and A. tuberculata is not harvested for human consumption (Vrgoč et al. 2009). Empty shells and occasional live specimens, are collected sporadically for decorative purposes. Therefore, the A. tuberculata populations can be regarded as virgin stocks and used to analyze natural variations in population structure, age and growth.

The age and growth of other cardiid species, mostly of the genus Cerastoderma, have been extensively studied. Orton (1926) showed that growth rings in $C$. edule were formed annually during the winter. Although there were disturbance rings on the shells it was possible to distinguish them from annual rings. Brock (1980) also counted the external growth rings and growth lines from bivalve shell sections to carry out age determination. However, some researchers have found these methods to be inappropriate for aging Cerastoderma populations (Guevara and Niell 1989, De Montaudouin 1996). As there have been no previous investigations into the age and growth of $A$. tuberculata, the first objective of this study was to identify a suitable aging method for this species. Once this had been established, we applied the method to analyze and interpret data on growth, age and the population struc-

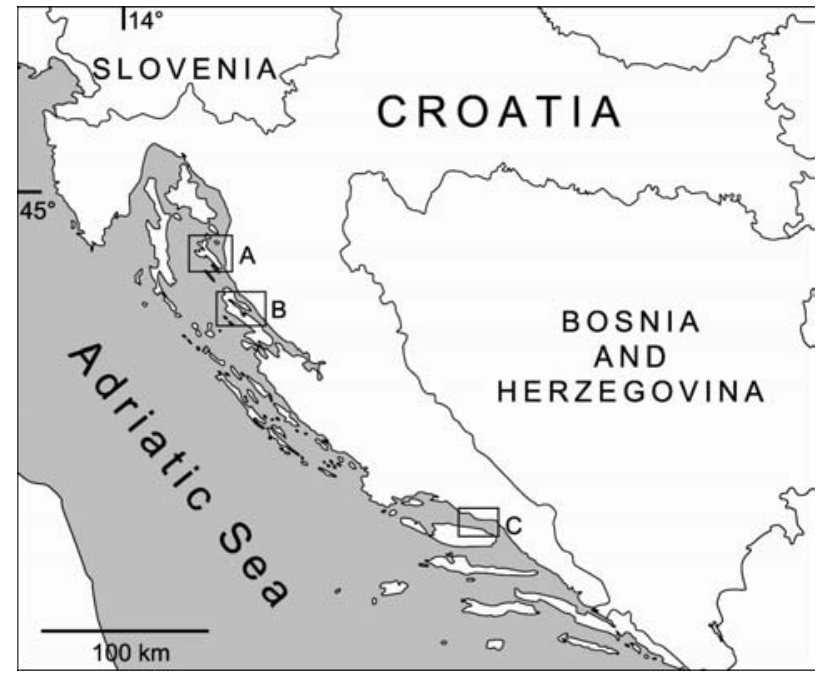

FIG. 1. - Map of the Adriatic Sea indicating the positions of the three sampling areas: A. Rab Island $\left(44^{\circ} 47^{\prime} \mathrm{N}, 1^{\circ} 42^{\prime} \mathrm{E}\right)$; B. Pag Bay $\left(44^{\circ} 28^{\prime} \mathrm{N}, 15^{\circ} 01^{\prime} \mathrm{E}\right)$; C. Cetina River estuary $\left(43^{\circ} 26^{\prime} \mathrm{N}, 16^{\circ} 41^{\prime} \mathrm{E}\right)$.

ture of A. tuberculata collected from different populations along the east Adriatic coast.

\section{MATERIALS AND METHODS}

Samples of Acanthocardia tuberculata were collected by a hydraulic dredge (horizontal dredge opening $=2.2 \mathrm{~m}$; blade cutting depth $=15 \mathrm{~cm}$; grid distances $=8-20 \mathrm{~mm}$ ) deployed at depths from 2.5 to $6.0 \mathrm{~m}$ in coastal waters along the eastern Adriatic Sea. Sampling was conducted during May 2008 in the Cetina River estuary and in November 2008 from around Rab Island and within Pag Bay (Fig. 1). Specimens were collected by 3 hydraulic dredge hauls from the Rab area, and 5 hauls each in Pag Bay and the Cetina River estuary. For a detailed description of the dredge sampling procedures see Peharda et al. (2010). Samples were used for comparative age analysis (described below) of the cockle populations of the three areas.

In addition, at monthly intervals during the period from March 2009 to February 2010, 30 similar-sized individuals were collected from the Cetina River estuary (Fig. 1) using SCUBA at depths between 1 and 3 $\mathrm{m}$. Siphon holes on the sediment surface were used to locate individuals, which were removed from the sediment using a metal stick. All individuals were stored frozen for later analysis. In the laboratory, the frozen samples were thawed and their condition indices determined. The shell length of each individual was measured with vernier callipers to the nearest $0.1 \mathrm{~mm}$. The mean shell length of individuals used for this analysis was $44.0 \pm 3.6 \mathrm{~mm}$. Individuals were cooked in boiling water for 2 minutes, the soft tissue was removed from the shell and both the tissue and shell were left to dry in the air for one hour. The weight of the flesh and shell of each individual was determined to the nearest 0.01 $\mathrm{g}$. The condition index $(\mathrm{CI})$ was determined as the ratio between wet flesh weight and the sum of flesh weight 


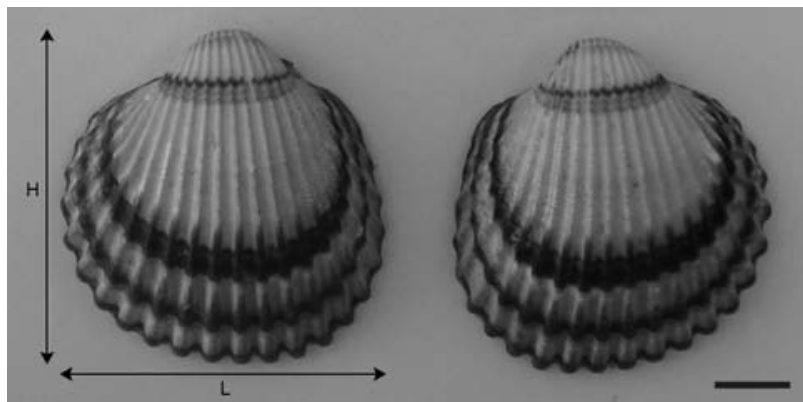

FIG. 2. - Photograph illustrating alternating dark (summer) and light (winter) growth bands on the external shell surfaces of the shell valves of a specimen of Acanthocardia tuberculata. Scale bar $=10$ $\mathrm{mm}$. L, length; $\mathrm{H}$, height.

plus shell weight (Davenport and Chen 1987). The shells were archived for growth and age analysis. Levene's test for homogeneity of variance was performed, as variances were homogenous one-way ANOVA was used to investigate differences in individual CI between months. The timing of a pronounced decrease in CI was assumed to correspond to the loss of gametes during the reproductive peak, and allowed us to estimate an approximate 'birth date' for the cockles of this population (c.f. Tarnowska et al. 2009). Environmental temperatures and salinities (for comparisons with $\mathrm{CI}$ values) were measured at monthly intervals with a YSI - Pro probe held above the sea bed at a depth of $2 \mathrm{~m}$ within the Cetina River estuary site.
Preliminary observations revealed a series of dark and light rings on the external shell surface of this species (Fig. 2). Two methods were used to validate the timing of the formation of these rings: 1) acetate peel replicas of shell sections, and 2) marginal increment analysis (Richardson 2001). Ten shells (shell length 32.5-59.7 $\mathrm{mm}$ ) were embedded in epofix resin (Struers), sectioned from the umbo to the ventral edge, ground, polished and etched for one minute in $0.1 \mathrm{M}$ $\mathrm{HCl}$, acetate peel replicas were then prepared (Richardson 2001). Numbers of dark and light growth rings on the external shell surface were then compared with the number of growth lines in acetate peel replicas of the umbonal region and prismatic shell layer. Observations confirmed that the number of growth lines in the umbonal region and prismatic shell layer corresponds to the number of dark rings on the external shell surface (Fig. 3); therefore, analysis of the rings on the external shell surface is a suitable method for aging A. tuberculata if its formation periodicity is known.

The formation periods of the dark and light rings were analyzed with marginal increment analysis. The distance between the last dark ring and the shell margin was measured in a total of 141 shells (length from 30.0 $\mathrm{mm}$ to $52.4 \mathrm{~mm}$ ) collected monthly from the Cetina River estuary over a one year period. The mean sample size per month was $11.8 \pm 5.4$ individuals. With respect to month, the smallest numbers of younger shells $(\mathrm{N}=7)$ were collected in May $(40.9 \pm 3.6 \mathrm{~mm})$, Sep-

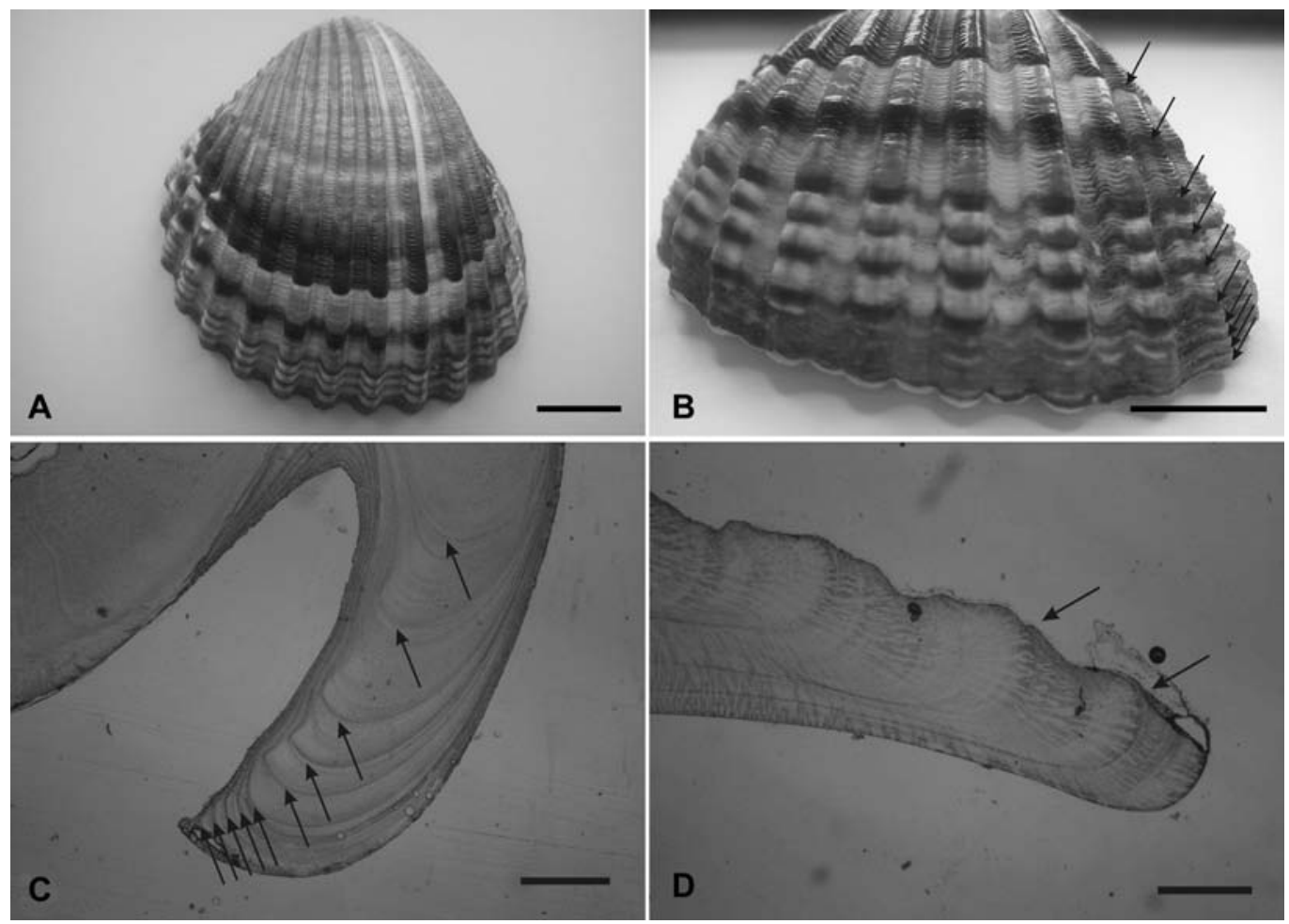

FIG. 3. - Photograph of an 11 year-old Acanthocardia tubeculata from the Cetina River estuary with no visible first growth ring (A). Black arrows indicate the positions of the 10 growth rings on the shell surface (B). Scale bar $=10 \mathrm{~mm}$. Photomicrographs of acetate peels of sections through the hinge region (C) and inner shell layer (D). Black arrows indicate the positions of the last 10 growth lines in the hinge area and 2 growth lines in the inner shell layer. Scale bar $=500 \mu \mathrm{m}$. 
tember (43.4 $\pm 3.1 \mathrm{~mm})$ and December 2009 (38.8 \pm 4.3 $\mathrm{mm})$, while 22 individuals were collected in June 2009 $(44.1 \pm 3.9 \mathrm{~mm})$.

We applied these findings in order to estimate the age of shells collected by hydraulic dredge from Rab Island, Pag Bay and Cetina River estuary. Shell lengths of these individuals ranged from 19.7 to $62.9 \mathrm{~mm}$, with a mean value of $41.21 \pm 8.96 \mathrm{~mm}$. Age, growth and population structure were analyzed for a sample of 381 shells collected by hydraulic dredge. Of these, 27 $(7.1 \%)$ individuals were omitted from the analysis as they did not have external dark and light rings.

Age and growth parameters, asymptotic height $\left(\mathrm{H}_{\infty}\right)$ and the growth constant $(\mathrm{k})$ were estimated from a Gulland-Holt plot using the annual increment data obtained from measurements of the distances between consecutive annual increments observed on the external shell surface. This method enables species growth parameters to be estimated without knowing the estimated age at a certain growth ring. This is especially important in the case of the first growth ring that is often not clearly visible. Asymptotic length was estimated based on the relationship between shell length and height of individuals collected with the hydraulic dredge:

$$
\mathrm{L}=0.977 \mathrm{H}+0.816\left(\mathrm{r}^{2}=0.97, \mathrm{~N}=381\right)
$$

In addition, the von Bertalanffy growth equation $\mathrm{L}_{\mathrm{t}}=\mathrm{L}_{\infty}\left(1-\mathrm{e}^{-\mathrm{k}(\mathrm{t}-\mathrm{to})}\right)$ was fitted to the length-at-age data using non-linear least-squares parameter estimation, where $\mathrm{L}_{\mathrm{t}}$ is the length at time $\mathrm{t}, \mathrm{L}_{\infty}$ is the asymptotic length, $\mathrm{k}$ is the growth constant, and $\mathrm{t}$ is the age at which $\mathrm{L}_{\mathrm{t}}=0$ (Gulland 1983). Growth performance indices $\left(\varnothing^{\prime}=\log \mathrm{k}+2 \log \mathrm{L}_{\infty}\right)$ were calculated for comparisons between growth in different populations (c.f. Sparre and Venema 1998).

\section{RESULTS}

Temperatures recorded from the Cetina River estuary showed seasonal variations (Fig. 4). Temperature values ranged from $24.4^{\circ} \mathrm{C}$ in July 2009 to $12.2^{\circ} \mathrm{C}$ in February 2010 , while temperatures $>19^{\circ} \mathrm{C}$ were recorded from May to October 2009. Salinity was variable due to the freshwater river inflow. Salinity values ranged from 27.5 psu in July 2009 to 39.4 psu in October 2009 (Fig. 4). Mean monthly values of Acanthocardia tuberculata CI ranged from 20.50 \pm 2.47 to $28.06 \pm 2.48$ (Fig. 5). The highest values were recorded in April 2009, while the lowest values occurred in the following month. CI values increased slowly from June onwards. These results suggest that $A$. tuberculata has one reproductive peak per year in the Cetina River estuary. The observed monthly differences in CI were statistically significant $(\mathrm{F}=11.02, \mathrm{p}<0.001)$. Based on condition index analysis, 15 May was set as the birthday for A. tuberculata.

Annual growth ring formation on the external shell surface of $A$. tuberculata was successfully vali-

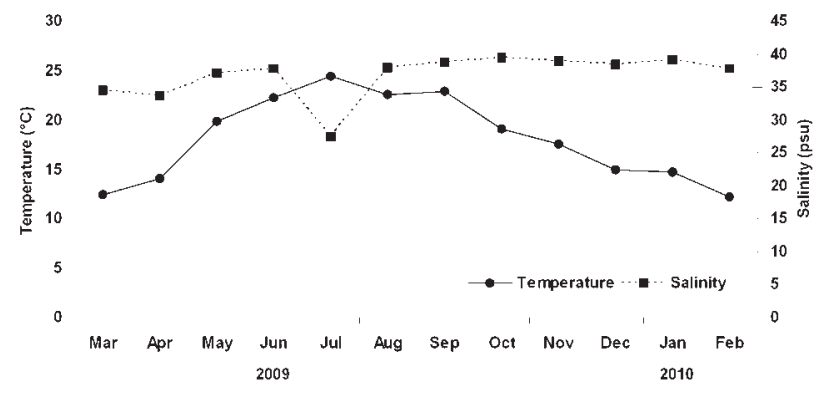

FIG. 4. - Monthly temperature and salinity values recorded at a depth of $2 \mathrm{~m}$ in the Cetina River estuary from March 2009 to February 2010.

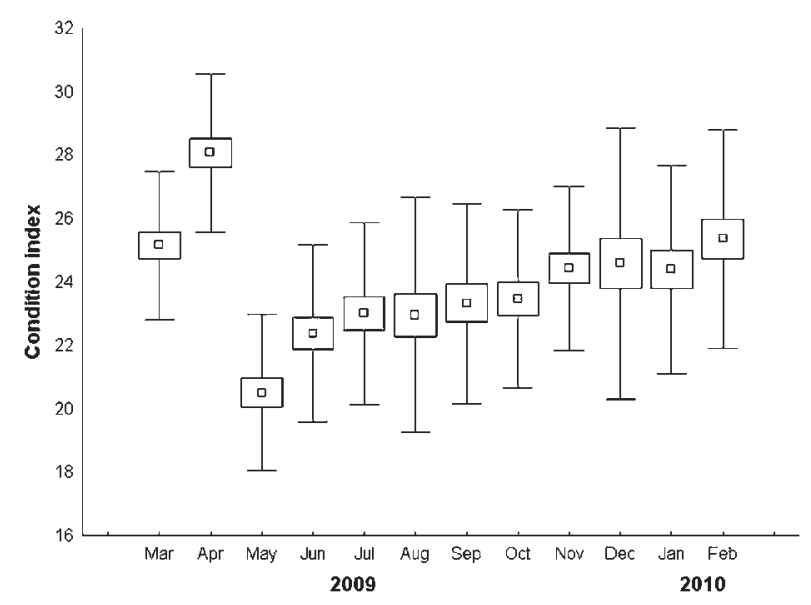

FIG. 5. - Seasonal variations in the condition index of Acanthocardia tuberculata collected using SCUBA in the Cetina River estuary. Values are means ( $\square$ ), standard errors (box) and standard deviations (whisker).

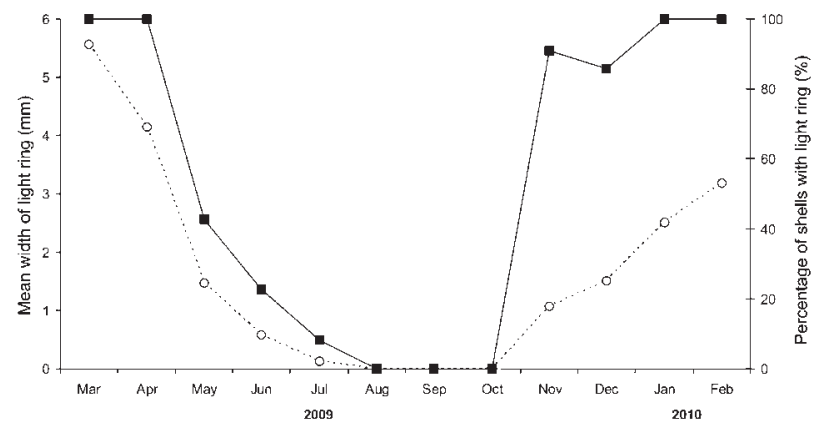

FIG. 6. - Marginal increment analysis of Acanthocardia tuberculata individuals $<4$ years old collected monthly from the Cetina River estuary. $\circ$, mean width of the most distal light ring on the shell (mm); ๓, percentage of shells with a distal light ring on the shell edge.

dated using two methods. Growth lines present in shell sections were clearly visible both at the hinge and in the inner shell layer (Fig. 3) and corresponded to the number determined for the external shell surface. Formation of the dark ring occurred in summer and all shells collected from August to October had a dark ring at their shell edges (Fig. 6). The dark ring started to form between April and May and 57\% of shells collected in May had a ring on the edge of the shell. The dark ring was completely formed by November, when $91 \%$ of analyzed shells had a light ring at the 

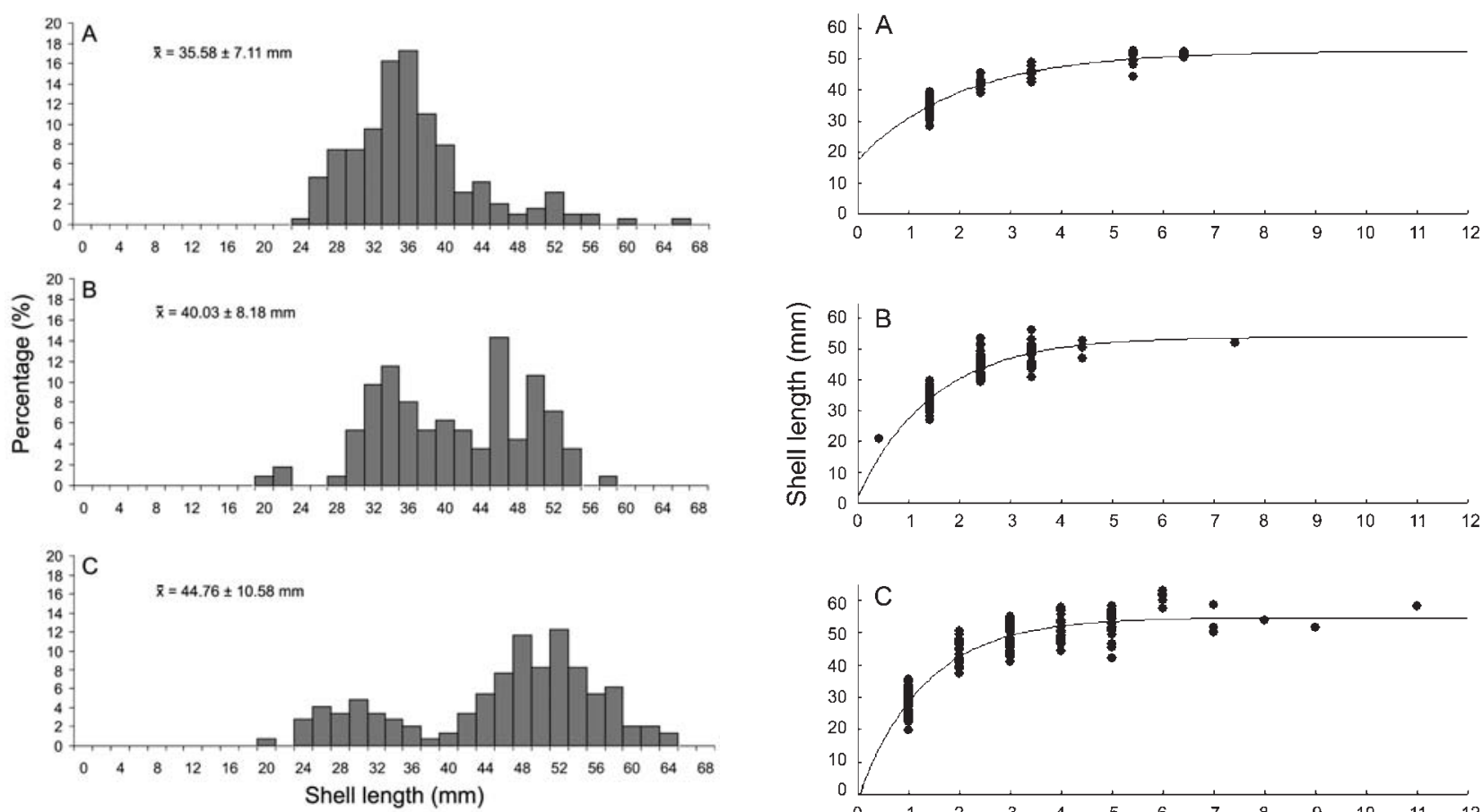

FIG. 7. - Population structure of Acanthocardia tuberculata from Rab Island (A), Pag Bay (B) and the Cetina River estuary (C). The mean length ( \pm standard deviation) is presented in each case.

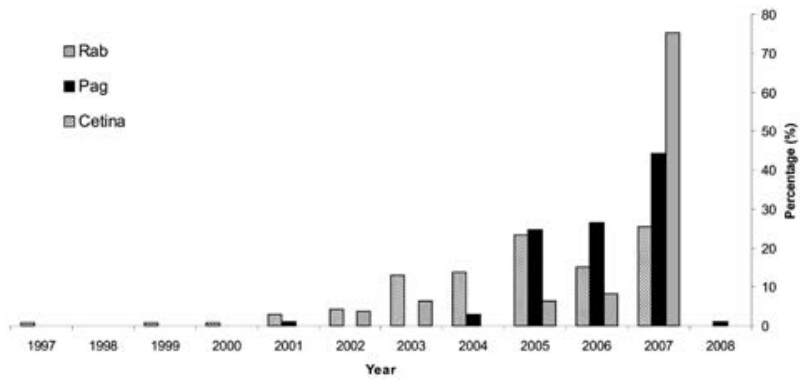

FIG. 8. - Recruitment frequency of Acanthocardia tuberculata into populations from three locations in the Adriatic Sea: Rab Island, Pag Bay and Cetina River estuary.

shell margin. The mean distance between the end of the last dark ring and the shell edge increased during the period from November to March. Based on annual ring validation, 15 November was set as the date that dark ring formation was complete, which indicates that the first dark ring visible on the external shell surface corresponded to an age of 6 months. A total of 53\% of the shells had a clearly visible first growth ring on the external shell surface. Acanthocardia tuberculata

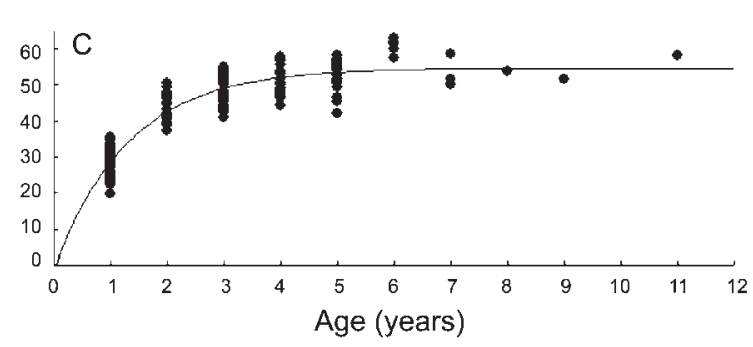

FIG. 9. - Age-at-length data obtained from the annually resolved growth lines in the shells of Acanthocardia tuberculata individuals collected from three locations in the Adriatic Sea: A. Rab Island; B. Pag Bay; C. Cetina River estuary. Von Bertalanffy growth curves are fitted to the data.

collected from around Rab Island ranged in age from 1 year and 5 months to 6 years and 5 months with a mean age of $2.07 \pm 1.37$ years $(\mathrm{N}=122)$. Samples collected from Pag Bay ranged in age from 5 months to 7 years and 5 months $(2.42 \pm 1.04$ years, $\mathrm{N}=102)$, while samples collected from the Cetina River estuary ranged in age from 1 to 11 years $(3.12 \pm 1.90$ years, $\mathrm{N}=130)$. Overall, $88 \%$ of individuals were $<4$ years old. The population shell length structure also showed differences between sampling areas (Fig. 7). Differences in shell length composition corresponded with differences in age composition: mean shell length values were highest in the Cetina River estuary, intermediate in samples from Pag Bay and lowest in Rab Island cockles. The recruitment years according to the sampling locations are shown in Figure 8. In samples from Rab Island, individuals recruited into the population in 2007 dominated the samples. In Pag Bay, an important recruitment period was identified as occurring from 2005 to 2007, while in the Cetina River estuary, the population

TABLE 1. - Gulland-Holt equations estimated from shell growth measurements on the external shell surface of specimens of Acanthocardia tuberculata collected from three sampling areas; $\mathrm{r}^{2}$, correlation coefficient; von Bertalanffy growth parameters estimated from the GullandHolt equation: $\mathrm{k}$, growth constant $\left(\mathrm{k}\right.$ year $\left.{ }^{-1}\right) ; \mathrm{H}_{\infty}$, asymptotic height $(\mathrm{mm}) ; \mathrm{L}_{\infty}$, asymptotic length (mm) calculated from the shell length/shell weight relationship; $\varnothing$, growth performance index.

\begin{tabular}{llllrr}
\hline Sampling area & Gulland-Holt equation & $\mathrm{r}^{2}$ & $\mathrm{k}$ & $\mathrm{H}_{\infty}$ & $\mathrm{L}_{\infty}$ \\
\hline Rab Island & $\mathrm{Y}=36.458-0.688 \mathrm{X}$ & 0.901 & 0.688 & 52.99 & 52.59 \\
Pag Bay & $\mathrm{Y}=29.225-0.485 \mathrm{X}$ & 0.703 & 0.485 & 3.28 & 60.24 \\
Cetina River estuary & $\mathrm{Y}=35.467-0.630 \mathrm{X}$ & 0.756 & 0.633 & 56.30 & 59.67 \\
\hline
\end{tabular}


TABLE 2. - Comparison of the estimated von Bertalanffy growth parameters for Acanthocardia tuberculata collected from three sampling areas; $\mathrm{k}$, growth constant (year-1); $\mathrm{L}_{\infty}$, asymptotic length $(\mathrm{mm}) ; \mathrm{r}^{2}$, correlation coefficient; $\mathrm{t}_{0}$, initial condition parameter; and $\emptyset$, growth performance index.

\begin{tabular}{lccccc}
\hline Sampling area & $\mathrm{k}$ & $\mathrm{L}_{\infty}$ & $\mathrm{t}_{0}$ & $\mathrm{r}^{2}$ & $\emptyset^{\prime}$ \\
\hline Rab Island & 0.487 & 52.65 & -0.832 & 0.915 & 3.13 \\
Pag Bay & 0.669 & 54.02 & -0.062 & 0.905 & 3.29 \\
Cetina River estuary & 0.767 & 54.65 & 0.030 & 0.925 & 3.36 \\
\hline
\end{tabular}

mainly comprised individuals recruited from 2003 to 2007. The results strongly indicate that A. tuberculata is a relatively short-lived (4-6 years) species.

Shell deposition was fastest during the first two years of life (13-26 mm year ${ }^{-1}$ ) when Acanthocardia tuberculata attained a length of $\sim 40 \mathrm{~mm}$ (Fig. 9). Shell growth rate significantly decreased after the $4^{\text {th }}$ year. The results of applying the Gulland-Holt method to growth increment data are presented in Table 1, while the population growth curve data generated from the length-at-age data are shown in Table 2. Relatively similar growth constant values were obtained from the different sampling areas, whichever method was used. Values of $\mathrm{L}_{\infty}$ ranged from $52.6 \mathrm{~mm}$ (Rab Island) to $59.7 \mathrm{~mm}$ (Pag Bay). The growth constant $\mathrm{k}$ showed somewhat higher variations ( 0.49 to 0.77 year $\left.^{-1}\right)$, while the growth performance index values ranged from 3.13 to 3.36 .

\section{DISCUSSION}

Different methods have been applied successfully in previous studies to determine age and growth in numerous bivalve species as well as to investigate the effects of environmental factors on age and growth. The most commonly used methods are based on analyzing external surface rings, internal growth lines and micro-growth bands in bivalve shells (for a review see Richardson 2001). Although external surface rings were not clear enough for age determination in some studied populations (e.g. Guevara and Niell 1989, De Montaudouin 1996), other cardiid populations showed clear, distinct annual rings on the shell surface (e.g. Orton 1926, Jones 1979, Brock 1980, Bourget and Brock 1990, Genelt-Yanovskiy et al. 2010) and external annual rings were visible as a band in the shell section (Brock 1980, Bourget and Brock 1990). Aging based on surface rings in C. edulis can be difficult as the disturbance rings are indistinguishable from annual marks. Age determination based on shell sections has proven to be more reliable because the annual marks are easily distinguished from stress marks. The gradual decrease in thickness of the micro growth increments in annual marks is recognized easily in comparison with the more abrupt cessation of growth caused by stress (Bourget and Brock 1990).

Although Acanthocardia tuberculata is exploited commercially in some parts of the Mediterranean, including Spain and Morocco (Taleb et al. 2001, Vale and Sampayo 2002, Ramón et al. 2005, Robles 2010), this is the first study on aging methods for this species.
According to Marano et al. (1980), A. tuberculata has one reproductive peak in the south Adriatic Sea, which in 1978 occurred between May and June. Although it was not an objective of our study to investigate the reproductive cycle of $A$. tuberculata, indirect data were obtained from the analysis of the CI. In the Cetina River estuary, a peak in CI occurred between April and May during the study period; this coincided with an increase in seawater temperatures. This is one month earlier than the results obtained by Marano et al. (1980). This discrepancy in timing may be due to inter-annual differences in environmental factors, including hydrographic conditions and food availability. The two coinciding sets of results suggest that this species has a uni-modal pattern of recruitment in the Adriatic Sea.

The results of our study indicate that analysis of the external surface rings is a reliable and convenient method for analyzing growth and age in A. tuberculata. Although the first winter ring was visible in only $53 \%$ of analyzed specimens, subsequent growth rings were clearly visible on the majority of specimens $(92 \%)$ and the method was validated by acetate peel replicas of shell sections and marginal increment analysis. Annual growth rings on the external shell surface of $A$. tuberculata consist of a relatively dark, narrow ring deposited during the summerautumn period (May to October) and a wider, light ring deposited during winter-spring (November to April). The light rings represent periods of intensive growth, while the dark rings represent reduced growth rates. According to a 10 year monitoring survey (AZO Database: http:// jadran.izor.hr/azo/) conducted in the Cetina River estuary, higher concentrations of chlorophyll $a(0.263 \pm 0.102$ $\mathrm{mg} \mathrm{m}^{-3}$ ) were recorded during the winter period when shell growth of A. tuberculata was most intensive. A slower shell growth rate was recorded during the period when concentrations of chlorophyll $a$ were lower $\left(0.175 \pm 0.071 \mathrm{mg} \mathrm{m}^{-3}\right)$. The Cetina River estuary and Pag Bay are characterized as oligotrophic areas according to their chlorophyll $a$ concentrations. The biomass of phytoplankton in the Cetina estuary increases slightly during the winter months, probably due to river nutrient input (Antolić et al. 2010, Ninčević-Gladan, pers. comm.). The slow growth rate (dark ring) also corresponded to the months after reproduction when A. tuberculata, after a sharp decrease in CI, presumably renewed energy reserves before investing in somatic growth. The related species Cerastoderma edule was found to have intensive growth during the late spring and summer in populations of Northern Ireland, UK, and limited growth during the winter when food (measured as chlorophyll $a$ ) is scarce (Seed and Brown 1978, Gowen and Bloomfield 1996). Cerastoderma was found to ripen rapidly during the spring and spawn over a relatively short period in the summer (Seed and Brown 1977). Evidently both Cerastoderma and Acanthocardia tuberculata grow faster when chlorophyll $a$ concentrations are high; however, this happens in different seasons in accordance with differences in abiotic and biotic environmental conditions as well as geographical position. It is interesting to note 
that both species showed their fastest shell growth rate immediately prior to gamete release. This indicates that they are able to gain sufficient energy for both growth and gametogenesis when food resources are adequate. The mean lengths of individuals collected in this study are similar to those recorded by Gaspar et al. (2002) for A. tuberculata collected along the Algarve coast, Portugal at depths <25 m (40.66 $\pm 17.21 \mathrm{~mm} ; \mathrm{N}=519)$. However, differences have been noted with respect to the size range of the shells in the two localities. The maximum shell length recorded in our study was $62.9 \mathrm{~mm}$, while on the Portuguese Atlantic coast it was $77.1 \mathrm{~mm}$ (Gaspar et al. 2002). Several factors could have influenced the observed differences in bivalve size range, such as the different sampling depths (García-March et al. 2007) and differences in the intensity of predation (Sanchez-Salazar et al. 1987), as well as differences in food availability. Differences in bivalve size could also be related to their geographical positions. A comparison of the shell length of three European populations of Cerastoderma glaucum showed that samples collected from the North Sea have larger specimens then those from the Mediterranean. Specimens collected from the Baltic Sea ware smaller than those from both the Mediterranean and North Sea (Tarnowska et al. 2009). According to Poppe and Goto (2000), A. tuberculata can attain a shell length of $90 \mathrm{~mm}$ but specimens of about $50 \mathrm{~mm}$ are more common. The intensive growth observed in A. tuberculata during its first year has been described previously for many bivalve species, including the related species $C$. edule, which grows fastest during the first two years of life (Seed and Brown 1978). However, the growth rate of $C$. edule varies greatly with location and period of immersion (Guevara and Niell 1989). Since Poppe and Goto (2000) reported that the shell length of $A$. tuberculata could reach a maximum length of $90 \mathrm{~mm}$, it would clearly be of interest to conduct a similar study in other parts of this species' distribution range in order to compare growth rates and determine whether population age structure and/or individual maximum sizes differ significantly between locations, and if so whether or not this is primarily related to different growth rates.

The approximate lifespan of a species can be estimated by dividing the number 3 by the value of the growth constant $\mathrm{k}$ (King 1995). Values of $\mathrm{k}$ recorded in our study ranged from 0.49 to 0.77 year $^{-1}$, which indicates that the estimated life span of A. tuberculata in the eastern Adriatic is 4-6 years. This agrees with our data on population age structure, since only $12 \%$ of analyzed individuals from hydraulic dredge samples were older than 4 years, and only $2 \%$ were older than 6 years. The maximum life span (also known as ecological longevity) determined from growth rings on the external shell surface and umbonal region for $A$. tuberculata in our study area was estimated to be 11 years. Using the example of Cerastoderma edule, Beukema (1988) evaluated bias in estimates of maximum life span and considered this to be highly dependent on sampling effort, even for short-lived species such as cockles. The oldest specimens of $C$. edule found in North Ireland (Seed and Brown, 1978) were 10 to 11 years old, while Cole (1956) found a single specimen on the English coast that was 16 years old. Taking into account the size of the individuals obtained in this study $(63 \mathrm{~mm})$ and a maximum size for the species of $90 \mathrm{~mm}$ (Poppe and Goto, 2000), it is possible that in other parts of the Mediterranean the ecological longevity of $A$. tuberculata is significantly greater than in the eastern Adriatic.

Although at present Acanthocardia tuberculata is not a commercially important species in most parts of the Mediterranean, shifts in market demands for seafood may occur in the future. For example, Vale and Sampayo (2002) suggested that harvesting A. tuberculata, although the species is not very abundant, could be a useful alternative for reducing harvest pressure on other species.

The present paper describes a convenient and robust methodology for aging $A$. tuberculata, and thereby provides information on the species' age, growth and population structure in the eastern Adriatic Sea. Our methodology and findings can be applied readily in other regions inhabited by this species. This will facilitate implementation of sustainable resource management in the areas where A. tuberculata is exploited, now or in the future.

\section{ACKNOWLEDGEMENTS}

This research was financed by the European Commission PHARE 2005 project "Assessment of demersal fish and shellfish stocks commercially exploited in Croatia", Croatian Ministry of Science and Technology grant N. 001-0013077-0532 "Biodiversity and sustainable management of pelagic and demersal resources in the Adriatic". The authors are grateful to Mario Zokić and Leo Brajković for technical assistance. Special thanks to Barbara Zorica for her help with the statistical analyses and Prof Brian Morton and Prof John Davenport for suggestions which improved the manuscript.

\section{REFERENCES}

Antolić B., Beg Paklar G., Bogner D., Bojanić N., Cvitković I., Dadić V., Despalatović M., Grbec B., Grubelić I., Krstulović N., Kršinić F., Kušpilić G., Marasović I., Matić F., Matić Skoko S., Matijević S., Mikac N., Milun V., Morović M., Nikolić V., Ninčević Gladan Ž., Pallaoro A., Pavlović M., Pezo I., Prelesnik H., Šolić M., Vidjak O., Vilibić I., Žuljević A., Veža J. 2010. Kontrola kakvoće obalnog mora Projekt Pag-Konavle 2009. Report, Institute of Oceanography and Fisheries, Split, 240 pp. (in Croatian)

Berenguer J.A., Gonzales L., Jimenez I., Legarda T.M., Olmedo J.B. 1993. The effect of commercial processing on the paralytic shellfish poison (PSP) content of naturally-contaminated Acanthocardia tuberculatum L. Food Addit. Contam. A 10: 217-230.

Beukema J.J. 1988. Bias in estimates of maximum life span, with an example of the edible cockle Cerastoderma edule. Neth. J. Zool. 39: 79-85.

Bourget E., Brock V. 1990. Short-term shell growth in bivalves: individual, regional, and age-related variations in the rhythm of deposition of Cerastoderma (=Cardium) edule. Mar. Biol. 106: 103-108. 
Brock V. 1980. Evidence of niche differences in sympatric populations of Cerastoderma edule and C. lamarcki. Mar. Ecol. Prog. Ser. 2: 75-80.

Castriota L., Scarabello M.P., Finoia M.G., Sinopoli M., Andaloro F. 2005. Food and feeding habits of pearly razorfish, Xyrichtys novacula (Linnaeus, 1758), in the southern Tyrrhenian Sea: variations by sex and size. Environ. Biol. Fish. 72: 123-133.

Cole H.A. 1956. A preliminary study of growth rate in cockles (Cardium edule L.) in relation to commercial exploration. J. Cons. Int. Explor. Mer. 33: 77-90.

Davenport J., Chen X. 1987. A comparison of methods for the assessment of condition in the mussel (Mytilus edulis L.). J. Molluscan Stud. 53: 293-297.

De Montaudouin X. 1996. Factors involved in growth plasticity of cockles Cerastoderma edule (L.), identification by field survey and transplant experiments. J. Sea Res. 36: 251-265.

Dreyer H., Steiner G. 2006. The complete sequences of gene organization of the mitochondrial genomes of the heterodont bivalves Acanthocardia tuberculata and Hiatella arctica - and the first record for a putative ATPase subunit 8 gene in marine bivalves. Front. Zool. 3:13.

García-March J.R., García-Carrascosa A.M., Peña Cantero A.L., Wang Y.G. 2007. Population structure, mortality and growth of Pinna nobilis Linnaeus, 1758 (Mollusca, Bivalvia) at different depths in Moraira bay (Alicante, Western Mediterranean). Mar. Biol. 150: 861-871.

Gaspar M.B., Santos M.N., Vasconcelos P., Monteiro C.C. 2002. Shell morphometric relationships of the most common bivalve species (Mollusca: Bivalvia) of the Algarve coast (southern Portugal). Hydrobiologia 477: 73-80.

Genelt-Yanovskiy E., Poloskin A., Granovitch A., Nazarova S., Strelkov P. 2010. Population structure and growth rates at biogeographic extremes: a case study of the common cockle, Cerastoderma edule (L.) in the Barents Sea. Mar. Pollut. Bull. 61: 247-253.

Gowen R.J., Bloomfield S.P. 1996. Chlorophyll standing crop and phytoplankton production in the western Irish Sea during 1992 and 1993. J. Plankton Res. 18:1735-1751.

Guevara J.M., Niell F.X. 1989. Growth rates in a continuously immersed population of Cerastoderma edule L. Sci. Mar. $53: 483-489$.

Gulland J.A. 1983. Fish stock assessment. A manual of basic methods. Wiley-Interscience, Chichister, $223 \mathrm{pp}$.

Hornung H. 1989. Metal levels in some benthic organisms of Haifa Bay, Mediterranean (Israel). Toxicol. Environ. Chem. 20: 255-260

Hrs-Brenko M., Legac M., Arko-Pjevac M. 1998. Contributions to the marine fauna of the Rijeka bay (Adriatic sea): 3. Bivalvia. In: Arko-Pjevac M., Kovačić M., Crnković D. (eds.), Natural history researches of the Rijeka region. Natural history library 1, Natural History Museum Rijeka, pp. 583-598.

Jones A.M. 1979. Structure and growth of a high-level population Cerastoderma edule (Lamellibranchiata). J. Mar. Biol. Ass. U.K. 59: 277-287.

Jukić S., Vrgoč N., Tonković M. 1998. A contribution to knowledge of distribution of the some commercially important sea shells, especially Chamelea gallina (L.), along the eastern Adriatic. Biol. Mar. Medit. 5: 376-381.

King M. 1995. Fisheries biology, assessment and management. Fishing News Books, Oxford, 352 pp.

Marano G., Casavolam N., Saracino C. 1980. A comparative study of the reproductive cycles of Chamelea gallina (L.), Venus verrucosa (L.), Rudicardium tuberculatum (L.) in the lower Adriatic Sea. Mem. Biol. Mar. Oceanogr. 10: 229-234.

Morello E.B., Froglia C., Atkinson R.J.A., Moore P.G. 2005. Hydraulic dredge discards of the Chamelea gallina fishery in the western Adriatic Sea, Italy. Fish. Res. 76: 430-444.

Official Gazette 63/2010. Pravilnik o obavljanju gospodarskog ribolova u moru. (in Croatian)

Orton J.H. 1926. On the rate of growth of Cardium edule. Part I. Experimental observations. J. Mar. Biol. Ass. U.K. 14: 239-279.

Peharda M., Ezgeta-Balić D., Vrgoč N., Isajlović I., Bogner D. 2010. Bivalve community structure in the Croatian part of the Adriatic Sea - a hydraulic dredge survey. Acta Adriat. 51: 141-157.

Poppe G.T., Goto Y. 2000. European seashells. Volume II.
Scaphopoda, Bivalvia, Cephalopoda. ConchBooks, Hackenheim, $221 \mathrm{pp}$.

Ramón M., Cano J., Peña J.B., Campos M.J. 2005. Current status and perspectives of mollusc (bivalves and gastropods) culture in the Spanish Mediterranean. Bol. Inst. Esp. Oceanog. 21: 361-373.

Richardson C.A. 2001. Molluscs as archives of environmental change. Oceanogr. Mar. Biol. Annu. Rev. 39: 103-164.

Robles R. 2010. Conservation and sustainable development of the Sea of Alborán / Conservación y desarrollo sostenible del mar de Alborán / Conservation et développement durable de la mer d'Alboran. Gland, Switzerland and Malaga, Spain: IUCN.

Rufino M.M., Gaspar M.B., Pereira A.M., Maynou F., Monteiro C.M. 2010. Ecology of megabenthic bivalve communities from sandy beaches on the south coast of Portugal. Sci. Mar. 74: 163-178.

Sagou R., Amanhir R., Taleb H., Vale P., Blaghen M., Loutfi M. 2005. Comparative study on differential accumulation on PSP toxins between cockle (Acanthocardia tuberculatum) and sweet clam (Callista chione). Toxicon 46: 612-618.

Sanchez-Salazar M.E., Griffiths C.L., Seed R. 1987. The effect of size and temperature on the predation of cockles Cerastoderma edule (L.) by the shore crab Carcinus maenas (L.). J. Exp. Mar. Biol. Ecol. 111:181-193.

Seed R., Brown R.A. 1977. A comparison of the reproductive cycles of Modiolus modiolus (L.), Cerastoderma (=Cardium) edule (L.), and Mytilus edulis L. in Strangford Lough, Northern Ireland. Oecologia 30: 173-188.

Seed R., Brown R.A. 1978. Growth as a strategy for survival in two marine bivalves, Cerastoderma edule and Modiolus modiolus. J. Anim. Ecol. 47: 283-292.

Sparre P., Venema S.C. 1998. Introduction to tropical fish stock assessment. Part 1, Manual. Manual. FAO Fisheries Technical Paper. No. 306/1, Rev.2. Rome, 407 pp.

Šiletić T. 2006. Marina fauna of Mljet national park (Adriatic Sea), Croatia: 5. Mollusca: Bivalvia. Nat. Croat. 15: 109-169.

Tagmouti-Talha F., Moutaouakkil A., Taib N., Mikou A., Talbi M., Fellat-Zerrouk K., Blaghen M. 2000. Detection of paralytic and diarrhetic shellfish toxins in Moroccan cockles (Acanthocardia tuberculata). Bull. Environ. Contam. Toxicol. 65: 707-716.

Takati N., Mountassif D., Taleb H., Lee K., Blaghen M. 2007. Purification and partial characterization of paralytic shellfish poison-binding protein from Acanthocardia tuberculatum. Toxicon 50: 311-321.

Taleb H., Vale P., Jaime E., Blaghen M. 2001. Study of paralytic shellfish poisoning toxin profile in shellfish from the Mediterranean shore of Morocco. Toxicon 39: 1855-1861.

Tarnowska K., Wolowicz M., Chenuil A., Féral J.P. 2009. Comparative studies on the morphometry and physiology of European populations of the lagoon specialist Cerastoderma glaucum (Bivalvia). Oceanologia 51: 437-458.

Vale P., Sampayo M.A.M. 2002. Evaluation of marine biotoxin's accumulation by Acanthocardia tuberculatum from Algarve, Portugal. Toxicon 40: 511-517.

Vale P., Taleb H. 2005. Assessment of the qualitative determination of paralytic shellfish poisoning toxins by pre-column derivatization and elimination of interfering compounds by solid-phase extraction. Food Addit. Contam. A 22: 838-846.

Vrgoč N., Peharda Uljević M., Krstulović Šifner S. 2009. Assessment of demersal fish and shellfish stocks commercially exploited in Croatia - Final Output o the European Union's PHARE 2005 Project: EuropeAid/123624/D/SER/HR program. Report, Institute of Oceanography and Fisheries, Split, $172 \mathrm{pp}$.

Zavodnik D., Šimunović A. 1997. Beskralješnjaci morskog dna Jadrana. Svjetlost, Sarajevo, 217 pp. (in Croatian)

Zenetos A., Vardala-Theodorou E., Alexandrakis C. 2005. Update of the marine Bivalvia Mollusca checklist in Greek waters. $J$. Mar. Biol. Ass. U.K. 85: 993-998.

Zolotoybko E., Quintana J.P. 2002. Non-destructive microstructural analysis with depth resolution: application to seashells. J. Appl. Crystal. 3585: 594-599.

Scient. ed.: M. Ramón.

Received September 2, 2010. Accepted June 9, 2011.

Published online November 21, 2011. 